\section{'White Regal', a Multiple-pest and Disease-resistant, Cream-fleshed Sweetpotato}

\author{
J.R. Bohac ${ }^{1}$ and P.D. Dukes, Sr. ${ }^{2}$ \\ U.S. Vegetable Laboratory, Agricultural Research Service, U.S. Department \\ of Agriculture, Charleston, SC 29414
}

J.D. Mueller ${ }^{3}$

South Carolina Agriculture and Forestry Research System, Clemson University, Blackville, SC 29817

\section{H.F. Harrison ${ }^{4}$, J.K. Peterson ${ }^{5}$, J.M. Schalk ${ }^{6}$, and D.M. Jackson ${ }^{7}$ U.S. Vegetable Laboratory, Agricultural Research Service, U.S. Department of Agriculture, Charleston, SC 29414}

J. Lawrence ${ }^{7}$

Caribbean Agricultural Research and Development Institute, University of the West Indies, Kingston, Jamaica

Additional index words. vegetable breeding, Ipomoea batatas, nematode resistance, soil insect resistance

The sweetpotato [Ipomoea batatas (L.) Lam.] cultivar White Regal was developed jointly by the U.S. Dept. of Agriculture (USDA), Agricultural Research Service (ARS), and the South Carolina Agriculture and Forestry Research System, Clemson Univ. This cultivar is a cream-fleshed, bland type with an attractive scarlet skin. Similar to 'Regal', it produces excellent yields of high quality storage roots, has a high level of resistance to diseases and insect pests, and is allelopathic to some weed species. 'White Regal' is a dry-fleshed, bland type in contrast to 'Regal', which is orange, sweet, and strong in sweetpotato flavor. 'White Regal' shows potential to be better for processed products than do orange, moist, sweet cultivars like Jewel and Beauregard. 'White Regal' should also be utilized instead of 'Regal' by breeders of dry-fleshed sweetpotatoes to transfer the multiple resistance traits of 'Regal', without introducing the sweetness and strong flavor not desired in these types. As a cultivar with multiple-pest and disease resistance, White

Received for publication 3 Mar. 2000. Accepted for publication 12 Oct. 2000. Technical contribution no. 4723 of the South Carolina Agriculture and Forestry Research System, Clemson Univ. The assistance of M. Hamilton, J.F. Fender, L. Still, and E.L. Corley is gratefully acknowledged. The cost of publishing this paper was defrayed in part by the payment of page charges. Under postal regulations, this paper therefore must be hereby marked advertisement solely to indicate this fact.

${ }^{1}$ Research Geneticist; to whom reprint requests should be addressed. E-mail: JBohac@.awod.com

${ }^{2}$ Research Plant Pathologist (retired).

${ }^{3}$ Professor.

${ }^{4}$ Research Agronomist.

${ }^{5}$ Research Plant Physiologist.

${ }^{6}$ Research Entomologist (retired).

${ }^{7}$ Research Entomologist. a breeding line from the USDA program, was the maternal parent of 'Regal'.

Fig. 1. 'White Regal'sweetpotato [Ipomoea batatas (L.) Lam.].

\section{Description}

'White Regal' has large, dark-green, cordate leaves, some with very slight teeth on the margin. The leaf blade has prominent dark purplish veins on the lower surface, radiating from the juncture of the petiole. The vines are moderate in length, vigorous, and the canopy develops rapidly and shades the ground. Several years of observation in South Carolina have shown that the bedded roots sprout rapidly in the spring, and more shoots are produced per flat of seed roots than is the case with the leading cultivars Jewel and Beauregard. 'White Regal' flowers profusely without grafting and produces large amounts of viable seed. These traits make 'White Regal' a good parent for use in polycross breeding nurseries.

'White Regal' is highly resistant to Fusarium wilt [Fusarium oxysporum f. sp. batatas (Wr.) Snyd. \& Hans] (Dukes et al., 1993b) and the southern root-knot nematode [Meloidogyne incognita (Kofoid and White) Chitwood, races 1 and 3] (Table 1) (Dukes et al., 1993a). 'White Regal' does not exhibit the symptoms of internal cork virus (caused by a strain of the sweetpotato feathery mottle virus) under field conditions where symptoms are exhibited by the susceptible cultivar Porto Rico. 'White Regal' was observed to be free of symptoms of sclerotial blight (Sclerotium rolfsii Sacc.) under plant bed conditions where the susceptible check clone, W-13, exhibits disease symptoms and subsequently reduced sprouting. Methods of testing and evaluation are described in Jones et al. (1986).

The levels of resistance of 'White Regal' to damage by the Wireworm-DiabroticaSystena (WDS) complex are similar to those of 'Regal' (Table 2). The WDS complex includes the southern potato wireworm (Conoderus falli Lane), the tobacco wireworm (Conoderus vespertinus Fabricius), the

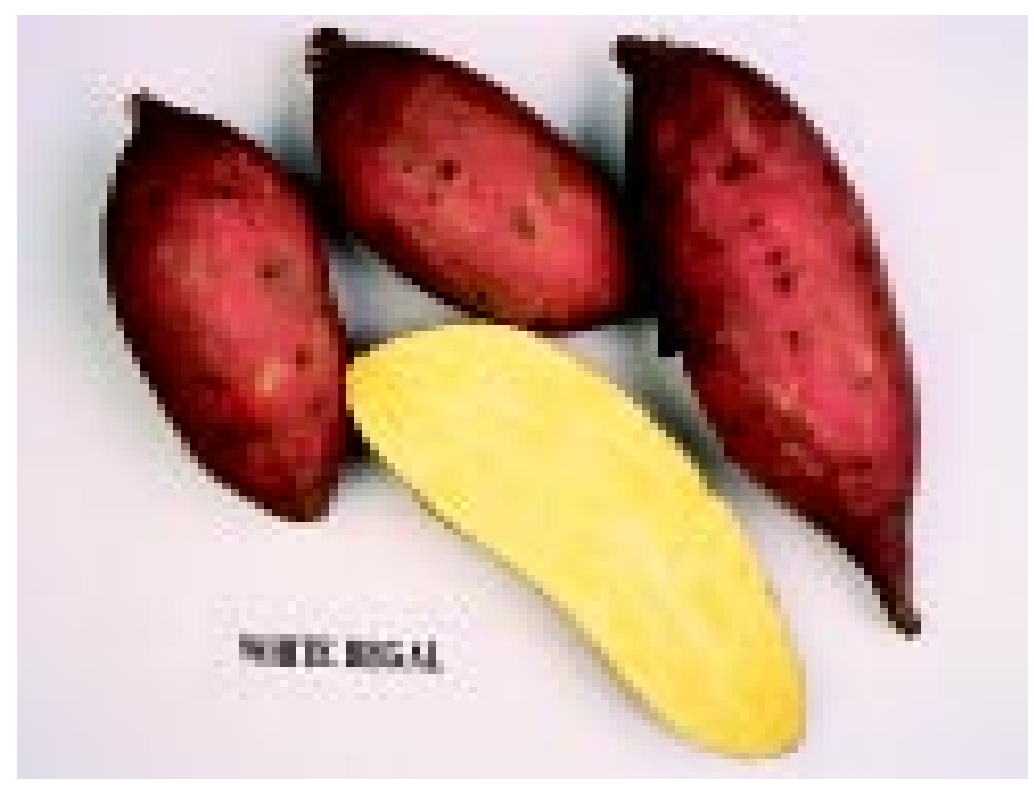


banded cucumber beetle (Diabrotica balteata Le Conte), and the spotted cucumber beetle (Diabrotica undecimpunctata howardi Barber). 'White Regal' is similar to 'Regal' in resistance to larvae of the white grub (Plectris aliena Chapin and Phyllophaga ephilida Say). Methods of testing and evaluation are described in Jones et al. (1982, 1986).

We also desired to evaluate the level of resistance of 'White Regal' to other insects in an environment different from that of South Carolina. Therefore, an experiment was conducted in Jamaica to determine the level of resistance to the local pest complexes (Lawrence, et al., 1998). In addition to resistance to the WDS complex, 'White Regal' was found to have moderate resistance to the sweetpotato weevil, Cylas formicarius (a damage index of 0.7 for 'White Regal' compared with an index of 2.2 for the susceptible standard SC1149-19). 'White Regal' also exhibited resistance to the grub of the sweetpotato leaf beetle species ( $4.1 \%$ of 'White Regal' roots were damaged compared with $20.5 \%$ for the susceptible standard SC1149-19). Since a red-skinned, white-fleshed cultivar is preferred to a copperskinned, orange-fleshed cultivar in Jamaica, 'White Regal' is being used in an integrated pest management (IPM) system designed to measure grower acceptance. 'White Regal', like its parent 'Regal', has been shown in field trials to have potential use in IPM systems (Lawrence et al., 1998; Schalk et al., 1993).

A greenhouse experiment was conducted to compare the allelopathic effects of 'Regal' and 'White Regal' on growth of yellow nutsedge (Cyperus esculentus L.) using the methods described by Harrison and Peterson (1991). Experimental conditions were designed to prevent competition for light, nutrients, and water. The sweetpotato cuttings were planted through holes $8 \mathrm{~cm}$ below the bucket rim to grow downward and prevent the vines from shading the nutsedge. Both 'Regal' and 'White Regal' cultivars strongly inhibited nutsedge growth (Table 3), which indicates that the allelopathic resin glycoside complexes present in 'Regal' (Peterson et al., 1998) are present at similar levels in 'White Regal'. Experiments conducted with 12 sweetpotato genotypes verified that the inhibition of yellow nutsedge was caused by the resin glycosides, and that there was a quantitative relationship between glycoside content and inhibition (Peterson et al., 1999). Genotypes without these glycosides did not inhibit the growth of nutsedge.

During the 1998 growing season, 114 sweetpotato clones were selected for genetic diversity. Many of these were from the USDA's world collection of diverse gemplasm. The clones were grown in two locations and roots were collected and the periderm analyzed for resin glycoside content. 'White Regal' was ranked eleventh in resin glycoside content in the periderm, with an average of $2.7 \%$ resin glycosides per total periderm dry weight. This high level of resin glycosides is correlated with the degree of allelopathy found in 'White Regal' (Table 3).

'White Regal' yields well and is similar to
'Regal' in the production of well-shaped roots (US \#1s). In 1992 trials, the total marketable yields (TMY) for 'White Regal' and 'Regal' were not significantly different from the leading sweetpotato cultivar Beauregard, but in 1994, 'Beauregard' was significantly higher (Table 4).

The storage roots of 'White Regal' are

fusiform and uniformly shaped, with an attractive scarlet skin and cream-colored flesh. Years of observation have shown that unlike other tropical, white-fleshed cultivars like Tanzania or Piccadito that deteriorate in a few weeks, 'White Regal' roots were in excellent condition after 9 months in storage. Very few roots showed damage or sprouting,

Table 1. Reactions of 'White Regal' and standard sweetpotato cultivars to Fusarium oxysporum $\mathrm{f}$. sp. batatas and Meloidogyne incognita-races 1 and 3 in a greenhouse test.

\begin{tabular}{|c|c|c|c|c|}
\hline \multirow[b]{2}{*}{ Entry $^{2}$} & \multicolumn{2}{|c|}{ Root knot nematode } & \multicolumn{2}{|c|}{ Fusarium wilt ${ }^{\mathrm{y}}$} \\
\hline & $\begin{array}{c}\mathrm{GI}^{\mathrm{x}} \\
(1-5)\end{array}$ & $\begin{array}{l}\text { EMI }^{\mathrm{w}} \\
(1-5)\end{array}$ & $\begin{array}{l}\mathrm{DI}^{\mathrm{v}} \\
(0-5) \\
\end{array}$ & $\begin{array}{l}\text { Plants killed }{ }^{u} \\
(\% \text { P. Rico) }\end{array}$ \\
\hline White Regal & 1.6 & 1.8 & 0.5 & 0 \\
\hline Regal & 1.8 & 1.9 & 0.6 & 0 \\
\hline Beauregard & 4.7 & 4.7 & 0.2 & 10 \\
\hline Jewel & 1.7 & 1.9 & 0.3 & 15 \\
\hline Sumor & 1.0 & 1.0 & 0.5 & 35 \\
\hline Porto Rico & 2.9 & 3.0 & 3.5 & 100 \\
\hline Sulfur & 4.4 & 4.0 & 4.3 & 100 \\
\hline $\mathrm{LSD}_{0.05}$ & 1.1 & 1.1 & 0.7 & 25 \\
\hline
\end{tabular}

${ }^{2}$ Vine cuttings with intact terminal buds were selected and cut from field-grown plants. Each cutting was trimmed and rooted in greenhouse benches containing sandy soil. For each entry, four replicates, including 10 cuttings per replication, were arranged in a randomized complete-block design. The rooted cuttings were inoculated with $\approx 2500$ freshly extracted $M$. incognita eggs. After $60 \mathrm{~d}$, roots were dug, washed, and evaluated under $\times 5$ magnification (Dukes et al., 1992). yVine cuttings were inoculated by dipping in an aqueous suspension of Fusarium spores $\left(10^{5} \cdot \mathrm{mL}^{-1}\right)$ and planted in a greenhouse bench. After $60 \mathrm{~d}$, roots were dug, washed, and evaluated under $\times 5$ magnification.

${ }^{\mathrm{x}}$ Gall index. Plants rated on scale of 1 to $5 ; 1=$ no galling, $5=$ severe galling, i.e. roots contain large numbers of galls (over one fourth of fibrous root area containing galls).

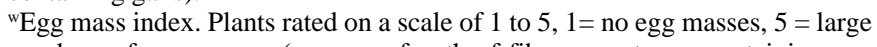
numbers of egg masses (over one-fourth of fibrous root area containing egg masses).

${ }^{\mathrm{v}} \mathrm{DI}=$ Disease index based on the rate of disease development, where $0=$ no disease, $5=$ all plants killed in $7 \mathrm{~d}$.

'Percentage of plants killed when all 'Porto Rico' (susceptible check) plants were dead.

Table 2. Reaction of 'White Regal' and 'Regal' sweetpotato to soil insects in South Carolina compared with susceptible breeding line SC1149-19.

\begin{tabular}{|c|c|c|c|c|}
\hline \multirow[b]{2}{*}{ Entry } & \multirow{2}{*}{$\begin{array}{l}\text { Noninjured } \\
\text { roots }(\%)\end{array}$} & \multirow{2}{*}{$\begin{array}{c}\text { WDS severity } \\
\text { index }^{z}\end{array}$} & \multicolumn{2}{|c|}{ Roots damaged (\%) by: } \\
\hline & & & SPFB $^{y}$ & Grub $^{x}$ \\
\hline White Regal & $56.0 \mathrm{a}^{\mathrm{w}}$ & $0.18 \mathrm{~b}$ & $0.0 \mathrm{~b}$ & $9.7 \mathrm{~b}$ \\
\hline Regal & $60.7 \mathrm{a}$ & $0.14 \mathrm{~b}$ & $0.7 \mathrm{~b}$ & $7.2 \mathrm{~b}$ \\
\hline SC1149-19 & $10.4 \mathrm{~b}$ & $1.13 \mathrm{a}$ & $14.4 \mathrm{a}$ & $43.5 \mathrm{a}$ \\
\hline
\end{tabular}

Table 3. Comparison of the allelopathic effect of 'Regal' and 'White Regal' sweetpotato clones on growth of yellow nutsedge.

\begin{tabular}{|c|c|c|c|c|}
\hline \multirow[b]{3}{*}{ Treatment } & \multicolumn{4}{|c|}{ Yellow nutsedge growth parameter } \\
\hline & \multicolumn{2}{|c|}{ Shoots } & \multicolumn{2}{|c|}{ Tubers } \\
\hline & (no./pot) & $(\mathrm{g} / \text { pot })^{\mathrm{y}}$ & (no./pot) & $(\mathrm{g} / \text { pot })^{\mathrm{y}}$ \\
\hline Yellow nutsedge (control) & 19 & 155 & 230 & 106 \\
\hline Yellow nutsedge $+\mathrm{Regal}^{2}$ & 11 & 74 & 116 & 61 \\
\hline Yellow nutsedge + White Regal & 12 & 70 & 115 & 58 \\
\hline $\mathrm{LSD}_{0.05}$ & 4 & 36 & 57 & 30 \\
\hline
\end{tabular}

${ }^{\mathrm{i}}$ Four pre-germinated yellow nutsedge tubers were planted 5-cm deep in 8-L plastic bucket containing a mixture of 1 field soil (Lynchburg loamy fine sand) : 1 commercial peat-vermiculite potting mixture. Two 15-cm 'Regal' or 'White Regal' vine cuttings were planted through holes 8 $\mathrm{cm}$ below the bucket rim to grow downward and prevent the vines from shading the nutsedge. ${ }^{y}$ Oven-dried. 
Table 4. Marketable yields of 'White Regal', 'Regal', and 'Beauregard' sweetpotatoes.

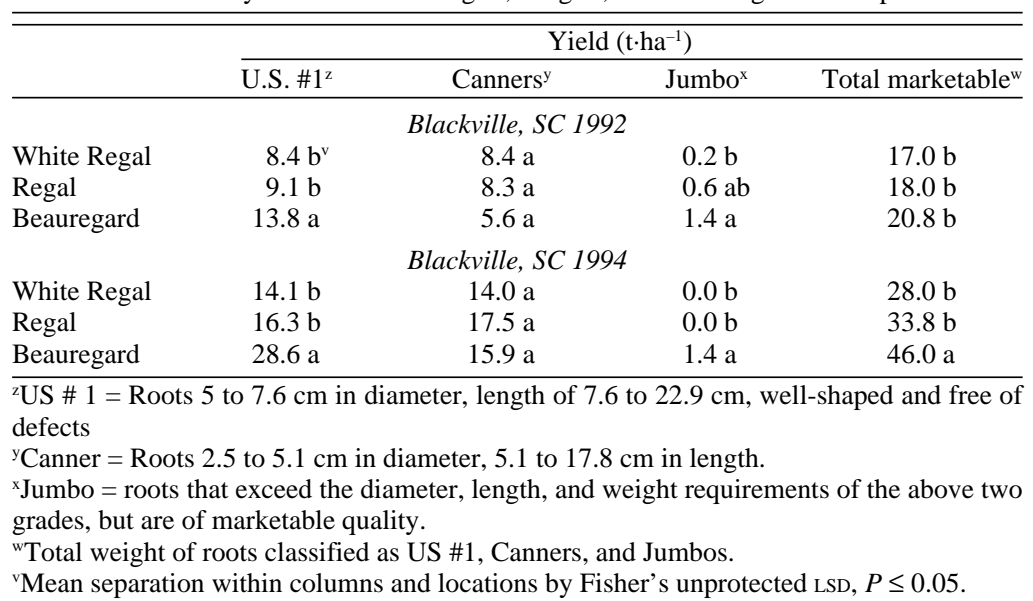

and the roots produced many shoots when placed in the planting beds. 'White Regal' was subjected to in-house baking tests over a 6-year period. 'White Regal' is blander in flavor, lower in sweetness, and dryer in texture than 'Regal'. It has excellent flavor, comparable with that of 'Sumor' (Dukes, et al., 1987), but moister and sweeter than 'HighDry' (Hamilton et al., 1985).

\section{Availability}

Limited quantities of foundation seed roots and cuttings will be available to breeders and other researchers for the 2002 crop season. Requests for plant material should be made no later than 15 June 2002, to Janice Bohac, U.S. Vegetable Laboratory, 2875 Savannah Highway, Charleston, SC 29414. Genetic material of this release will be deposited in the National
Plant Germplasm System where it will be available for research purposes, including development and commercialization of new cultivars.

\section{Literature Cited}

Dukes, P.D.., J.R. Bohac, J.M. Schalk, and J.D. Mueller. 1993a. Reactions of regional and advanced lines, standard cultivars, selected cultivars, and lines of sweetpotato to Southern root knot, 1992. Biological and Cultural Tests for Control of Plant Dis. 8:32.

ukes, P.D., J.R. Bohac, and J.D. Mueller. 1993b. Disease reactions of regional and advanced breeding lines, selected and standard cultivars of sweetpotato to stem rot, 1992. Biological and Cultural Tests for Control of Plant Dis. 8:33.

Dukes, P.D., M.G. Hamilton, A. Jones, and J.M. Schalk. 1987. 'Sumor', a multi-use sweet potato. HortScience 22:170-171.
Hamilton, M.G., P.D. Dukes, A. Jones, and J.M Schalk. 1985. 'HiDry' sweet potato. HortScience 20:954-955.

Harrison, H.F., Jr., and J.K. Peterson. 1991. Evidence that sweetpotato (Ipomeoa batatas) is allelopathic to yellow nutsedge (Cyperus esculentus). Weed Sci. 39:308-312.

Jones, A., P.D. Dukes, and J.M. Schalk. 1986. Sweet potato breeding, p. 1-35. In: M.J. Bassett (ed.). Breeding vegetable crops. AVI,Westport, Conn.

Jones, A., P.D. Dukes, J.M. Schalk, M.G. Hamilton, M.A. Mullen, R.A. Baumgardner, D.R. Patterson, and T.E. Boswell. 1985. 'Regal' sweet potato. HortScience 20:781-782.

Jones, A., J.M. Schalk, and P.D. Dukes. 1982.Progress in selection for resistances in sweetpotato to soil insects of the WDS Complex, p. 337-344. In: R.L. Villareal (ed.). Proc. First Intl. Symp. on Sweet Potato. Asian Veg. Res. and Dev. Ctr., Tainan, Taiwan, Republic of China.

Jackson, D.M., J.R. Bohac, J. Lawrence, and J.D. Mueller, 1998. Multiple Insect resistance in dryfleshed sweet potato breeding lines for the USA and Caribbean, p. 274-280. In: (eds.). Progress in IPM CRSP Research: Proceedings of the Third IPMCRSP Symposium. 15-19 May 1998. Va. Polytechnic Inst., Blacksburg, Va.

Peterson,J.K., H.F. Harrison, Jr. and A.E. Muckenfuss. 1998. Interference of sweetpotato glycosides with growth and survival of diamondback moth larvae (Lepidoptera: Plutellidae). Allelopathy J. 5:4352.

Peterson, J.K., H.F. Harrison, and M.E. Snook. 1999. Comparison of three parameters for estimation of allelopathic potential in sweetpotato [Ipomoea batatas (L. Lam.] germplasm. Allelopathy J. 6: 201-208.

SAS Institute. 1988. SAS/STAT guide, release 6.03 ed. SAS Inst., Cary, N.C.

Schalk, J.M., J.R. Bohac, P.D. Dukes, and W.R. Martin. 1993. Potential of non-chemical control strategies for reduction of soil insect damage in sweetpotato. J. Amer. Soc. Hort. Sci. 118: 605-608. 